\title{
MEMBANGUN GENERASI UNGGUL DENGAN BUDAYA LITERASI MELALUI KEPEMIMPINAN PENDIDIKAN
}

\section{Dede Ahmad Ghazali}

UIN Sunan Gunung Djati Bandung Jl. A.H. Nasution No. 105 Cibiru Bandung 40614

Email: dedeahmad@uinsgd.ac.id

\section{A. Heris Hermawan.}

UIN Sunan Gunung Djati Bandung Jl. A.H. Nasution No. 105 Cibiru Bandung 40614

Email: herishermawan@uinsgd.ac.id

\section{ABSTRAK}

Penelitian ini bertolak dari fenomena yang terjadi pada pesantren yang masih belum kuat mengembangkan budaya literasi dalam menciptakan generasi yang unggu melalui kepemimpinan pendidikan. Tujuan penelitian ini adalah untuk memahami budaya literasi terutama terkait dengan pola, respon dan tantangannya pada pesantren melalui kepemimpinan pendidikan. Dengan diketahuinya budaya literasi pada pesantren maka akan dapat mengembangkan keunggulan generasi mendatang. Penelitian ini berangkat dari pemikiran bahwa untuk dapat mengembangkan generasi yang unggul maka sangat diperlukan budaya literasi yang baik terutama di pesantren melalui kepemimpinan pendidikan. Metode penelitian yang dilakukan dalam penelitian ini adalah metode deskriptik dengan analisis logis. Pendekatan penelitian adalah kualitatif. Pengumpulan data dilakukan dengan melakukan wawancara dan observasi. Hasil penelitian menunjukkan bahwa telah terjadi budaya literasi pada lembaga pendidikan Islam pesantren dengan pola, respon dan tantangannya melalui kepemimpinan pendidikan yang berbeda antara pesantren al- aqsho dan al-Ihsan tetapi problem umumnya masih sama yaitu masalah SDM dan Fasilitas.

Kata Kunci: Generasi Unggul, Budaya Literasi, Kepemimpinan

\section{Abstract}

This study is based on the phenomenon that occurs in schools that are still not strong developing literate culture in creating a generation that unggu through leadership education. The purpose of this study is to understand the culture of literacy primarily related to the pattern, response and challenge to the schools through educational leadership. By knowing the literate culture at schools will be able to develop the next generation of excellence. This paper starts from the premise that in order to develop a superior generation so it will need a good literate culture, especially in schools through educational leadership. The 
research method in this research is descriptive method with logical analysis. The research approach is qualitative. Data was collected by interview and observation. The results showed that there was a culture of literacy in Islamic boarding school education institutions with a pattern, the response and the challenge through different educational leadership among schools of al-Aqsa and al-Ihsan but generally still the same problem, namely the problem of human resources and facilities.

Keywords: Generation of Excellence, Cultural Literacy, Leadership

\section{PENDAHULUAN}

Pentingnya arti literasi sesuai dengan tuntutan al Qur'an surat al-Alaq (1 - 5) yang mendorong manusia untuk membaca dan berpikir kritis, dan bahkan pemerintah secara tegas mendorong sekolah - madrasah - pesantren, sebagai garda terdepan dalam menciptakan generasi yang unggul dan melek baca tulis.

Pada perkembangannya, literasi tidak saja diartikan sekadar membaca dan menulis (Priangan, 2014) tapi juga mencakup menghitung dan berbicara (Ali, 2014), bahkan Priangan dan Ali melekatkan kata literasi dengan media, teknologi, dan informasi. Lebih lanjut Haryanti menyebutkan bahwa proses dalam membudayakan atau membiasakan untuk membaca, menulis itu diperlukan jika kebiasaan tersebut belum terbentuk dalam lingkungan masyarakat tertentu.

Pada penelitan ini, penulis mencoba mengungkap keberadaan budaya literasi di lingkungan pesantren. Ada beberapa alasan mengapa pesantren menjadi objek yang menarik untuk diteliti seperti yang dikemukakan oleh Alwasilah (2006). Pertama, perintah membaca (iqra) menjadi pegangan santri pesantren untuk memperoleh informasi sebanyak-banyaknya. Kedua, peninggalan ilmu fikih (yurispundensi Islam) beberapa madzhab. Oleh karena itu perlu urun pemikiran dan diskusi di pesantren. Terlebih lagi, textbook keislaman dari ulama-ulama besar (pemikir Islam) perlu dilestarikan jangan sampai punah. Bahkan kalau bisa, pemikiran kontemporer terhadap buku-buku pemikiran besar tersebut dapat dilanjutkan. Ketiga, makin tidak terbendungnya aliran informasi teknologi mengharuskan santri di pesantren untuk mengetahuinya sehingga pesantren tidak ketinggalan informasi.

Alwasilah lebih lanjut mencermati pentingnya literasi untuk diterapkan di pesantren merujuk pada "terpuruknya umat Islam, khususnya dalam bidang ilmu pengetahuan dan teknologi, adalah akibat mandeknya tradisi menerjemahkan dan menulis."Selama ini, menurut Alwasilah, bahwa santri dan masyarakat pada umumnya lebih banyak menerima dakwah secara lisan, sedangkan bahasa tulisan tidak banyak diexplor berupa produksi teks dalam bahasa daerah, Indonesia,maupun Arab, sehingga pesantren memerlukan perubahan kultur keilmuan dan literasi.

Kepemimpinan memiliki posisi yang penting dalam suatu organisasi. Suatu organisasi yang tidak memiliki kepemimpinan yang kuat dapat dipastikan organisasi tersebut akan mudah mengalami kemunduran. Tanpa kepemimpinan yang efektif suatu organisasi akan lemah dan memiliki masalah yang serius.

Kepemimpinan merupakan salah satu inti dari manajemen. Kreativitas dan aktivitas pemimpin sangat menentukan arah kebijakan dan ketercapaian 
tujuan organisasi.Seorang pemimpin yang kurang dinamis maka organisasi akan mengalami kondisi statis.Kepemimpinan yang baik akan sangat mempengaruhi moral dan kepuasan kerja suatu organisasi.

Oleh karena itu, kami memandang perlu adanya penelitian tentang budaya literasi di pesantren untuk melihat pola, respon, dan tantangan penerapannya di pesantren. Pola merujuk pada strategi budaya literasi yang diadopsi, dan respon terhadap penerapannya akan menentukan posisi keberadaan budaya literasi ini di lingkungan pesantren. Penelitian ini ditutup dengan diskusi tentang temuan terhadap tantangan penerapan budaya literasi di pesantren sehingga di kemudian hari dapat dilakukan cara perbaikan dalam penerapannya.

Penelitian ini bertujuan untuk melihat budaya literasi di pesantren. Pada penelitian ini akan dirumuskan tiga pertanyaan masalah penelitian sebagai berikut:

a. Seperti apakah pola strategi budaya literasi yang diterapkan di pesantren?

b. Bagaimana respon stakeholders terhadap penerapan budaya literasi di pesantren?

c. Apa saja tantangan yang dihadapi dalam menerapkan budaya literasi di pesantren?

d. Bagaimana kepemimpinan mengarahkan budaya literasi pada

\section{KAJIAN TEORI}

Pentingnya literasi telah ada dalam al Qurán surat Al-Alaq (ayat 1-5) sebagai perintah pertama dari Alloh SWT yang berisi sebagai berikut,

Bacalah dengan (menyebut) nama Tuhanmu yang menciptakan.Dia telah menciptakan manusia dari segumpal darah.Bacalah dan Rabbmu lah yang Maha Mulia.Yang mengajar (Manusia) dengan pena.Dia mengajarkan manusia apa yang tidak diketahuinya.(QS. Al Alaq: 1-5)

Sebagai pengejawantahan pentingnya literasi diatas, UIN Sunan Gunung Djati Bandung telah mewujudkan pentingnya literasi dalam motonya "Wahyu memandu ilmu." Moto ini berperan sebagai kerangka yuridis, payung dalam membudayakan literasi di UIN Sunan Gunung Djati Bandung. Berdasarkan kedua rujukan diatas, penelitian tentang budaya literasi di pesantren layak untuk diteliti.

Secara konsep, literasi telah mendapatkan banyak perhatian para pendidik karena kontribusinya terhadap peningkatan keilmuan (Alfiyah, 2016; Desfandi, 2015; Ruhaena, 2013; Sofa,2010). Saat ini banyak penelitian tentang budaya literasi dilakukan di sekolah umum (Sofa,2010; Ryndiasari, 2008), sedangkan di lingkungan pesantren penelitian terkait literasi ini masih sedikit (ideabadi.blogspot.co.id dalam menyoal budaya literasi di pesantren).Berdasarkan hal tersebut, penelitian ini ada untuk melengkapi khasanah penelitian tentang literasi di pesantren.

Diawali dengan beragamnya definisi literasi, para ahli mengembangkan literasi dari awalnya membaca dan menulis sampai menjadi basic keterampilan hidup (life skills) dan potensi keilmuan seseorang (Ali, 2014; Priangan, 2014). Hal ini masih terlihat dari adanya banyak definisi literasi yang ditanggapi berbeda oleh beberapa ahli (Alfiyah, 2016). Alfiyah merangkum beragam 
definisi literasi sebagai berikut. Konsep literasi pertama kali merujuk pada membaca dan menulis (Priangan, 2014); akan tetapi seiring jaman, literasi ini mencakup menghitung dan berbicara (Ali, 2014). Terakhir, definisi literasi merujuk pada keterampilan hidup mencakup pemerolehan informasi dan menjadi indikator potensi kompetensi keilmuan seorang siswa (Priangan, 2014). Unesco (dalam Prayesti, 2005) merangkum definisi literasi yang diadopsi dalam penelitian ini sebagai "the ability to identify, understand, interpret, create, communicate and compute, using printed and written materials associated with varying contexts."

Konsep literasi apabila dilihat dari sudut pandang budaya mengisyaratkan adanya sebuah kebiasaan (culture) yang terprogram dan dilakukan dengan sadar oleh institusi pembelajaran (Haryanti, 2014). Penerapan budaya literasi di pesantren tentunya menarik untuk diteliti mengingat budaya pembelajaran pesantren selama ini bersifat patriakal (Ma'mur, 2008), sedangkan dengan arus informasi yang cepat, pemerolehan informasi seharusnya tidak satu arah. Untuk itu, dalam penelitian ini, peneliti akan melihat jenis budaya literasi yang berkembang.

Pola strategi budaya literasi merujuk pada konsep bahwa sebuah strategi pembelajaran apapun namanya akan merujuk pada pola tertentu dalam penerapannya (Hatimah, 2016). Lebih lanjut pola tersebut timbul menyesuaikan dengan karakteristik strategi yang digunakan dan faktor luar yang berpengaruh dalam penerapannya. Secara umum, pola strategi literasi bersifat top down, artinya pihak yang memiliki otoritas yang memberikan instruksi dari atas ke bawah. Pola seperti ini bersifat paternalistik (Ma'mur, 2008), yaitu adanya instruksi dari guru ke siswa. Umumnya pola budaya literasi di pesantren termasuk dalam kategori paternalistik. Pola strategi budaya lainnya bersifat terprogram dan dilakukan secara sadar (Haryanti, 2014). Pola literasi seperti ini memerlukan kesadaran yang tinggi karena pola ini sudah memperlihatkan kesadaran para penggiatnya dalam menerapkan budaya strategi literasi ini. Pola strategi budaya literasi ada juga yang dikaitkan dengan kegiatan pembelajaran di kelas (Kemdikbud, 2016). Umumnya, guru memberikan tugas tambahan sehingga siswa secara tidak langsung dan tidak sadar akan membaca dan menulis untuk mengerjakannya. Beberapa pola strategi budayaliterasi di atas tentunya memiliki konsekuensi dalam penerapannya.

Paul Hersey and Blanchart dalam Diding Nurdin (2007:237) menyebutkan definisi kepemimpinan:

1. Leadership is the activity of influencing exercised to strive willingly for group objectives (George R. Terry);

2. Leadership as interpersonal influence exercised in situation and directed, through the comunication process, toward the attainment of a specialized goal the goals (Robert T, Irving R.Wischler, Fred Nassarik);

3. Leadership is influencing people to follow in the achievement of a common goal ( Harold Koonte and Cyril O'Donnell).

Pemahaman mengenai hubungan antara kepemimpinan dengan keunggulan (exellence) dalam pendidikan telah dibuat oleh Sergiovanni atas dasar penelitian terbarunya mengenai efektivitas sekolah dan sekolah yang istimewa (exellence). la mengidentifikasikan lima kekuatan (forces), yang 
dibutuhkan dalam rangka meningkatkan lembaga pendidikan yang unggul. Kelima kekuatan itu adalah: (1). Technical Force, (2). Human Force, (3). Educational Force (4). Symbolic Force, (5). Cultural Force (Veithzal dan Murni, 2009:316-317)

\section{METODOLOGI PENELITIAN}

\section{Metode Penelitian}

Penelitian ini dilakukan secara kualitatif untuk mendeskripsikan keberadaan budaya literasi di pesantren. Temuan penelitian utama diperoleh dari data interviu, dan didukung dengan temuan dari observasi lapangan. Metodologi penelitian berikut akan menjelaskan lokasi penelitian, koleksi data, interviu dan observasi lapangan, dan bagaimana data tersebut dianalisa.

2. Lokasi Penelitian

Penelitian ini digolongkan ke dalam multicase study (Wood, 1992, 22) yaitu meneliti di beberapa tempat (dalam hal ini pesantren). Pesantren yang dijadikan lokasi penelitian ini tergolong pada pesantre modern. Penelitian ini mengangap bahwa pesantren modern lebih mudah dalam memperoleh data, dan literasi erat kaitannya dengan arus informasi yang cepat dan tidak terbatas, dianggap bahwa pesantren modern memiliki akses pemerolehan informasi tersebut.Tabel berikut adalah dua pesantren yang akan dijadikan lokasi penelitian.

Tabel 1

Lokasi Penelitian

\begin{tabular}{|l|l|l|}
\hline No & \multicolumn{1}{|c|}{ Pesantren } & \multicolumn{1}{c|}{ Kota/kab } \\
\hline 1 & Pesantren Al-Ihsan, Baleendah & Kab. Bandung \\
\hline 2 & Pesantren Al-Aqso, Cibeusi & Kab.Sumedang \\
\hline
\end{tabular}

Data penelitian akan diperoleh dari hasil interviu pihak-pihak yang terlibat dalam pelaksanaan literasi di pesantren, pada awalnya direncanakan antara lain siswa, guru, kepala sekolah, dan tenaga kependidikan. Pertanyaan interviu dikategorikan berdasarkan tiga aspek yang diteliti, yaitu pola, respon, dan tantangan penerapan literasi. Waktu interviu sekitar 30 menit, dan dilaksanakan sesuai dengan waktu yang disediakan oleh pihak-pihak yang terlibat. Hasil interviu direkam untuk kemudian ditranscribe, dan dianalisa berdasarkan tiga aspek yang diteliti.

3. Pengumpulan data

Penelitian tentang budaya literasi di pesantren akan menjawab tiga pertanyaan masalah penelitian, antara lain (1) Seperti apakah pola strategi budaya literasi yang diterapkan di pesantren? (2) Bagaimana respon stakeholders terhadap penerapan budaya literasi di pesantren? (3) Apa saja tantangan yang dihadapi dalam menerapkan budaya literasi di pesantren? Ketiga pertanyaan diatas bertumpu pada dua sumber pengumpulan data yaitu interviu dan observasi lapangan.

Interviu sebagai alat pengumpulan data utama terdiri dari beberapa pertanyaan yang dikategorikan sesuai dengan tiga aspek yang diteliti, yaitu pola, respon, dan tantangan penerapan budaya literasi. Pertanyaan interviu didesain dalam bentuk semi-structure interview, artinya pertanyaan tambahan diperbolehkan untuk memperjelas jawaban. Data interviu akan ditranscribe dan 
dianalisa datanya sesuai tema yang diangkat (lihat tiga aspek yang diteliti diatas). Tidak semua data interviu akan digunakan, tetapi lebih disesuaikan dengan kebutuhan dalam pembahasannya (Miles and Huberman, 1984, 21). Interviu ini juga berlangsung selama maksimal 30 menit. Pelaksanaan interviu disesuaikan dengan waktu luang dari pihak-pihak yang terlibat.

Data pendukung kedua diperoleh dari observasi lapangan. Observasi lapangan dimaksudkan untuk melihat langsung kondisi pesantren dan keberadaan budaya literasi disana. Penelitian ini menyediakan rubrik observasi lapangan yang disesuaikan dengan keadaan di masing-masing pesantren. Hasil rubrik dianalisa berdasarkan kategori ya dan tidak terhadap pernyataan yang diamati. Hasil observasi lapangan ini akan menguatkan hasil interviu sehingga deskripsi budaya literasi di pesantren akan lebih jelas. Kejelasan temuan penelitian akan menentukan kekuatan penelitian kualitatif sehingga ketiga aspek pertanyaan penelitian bisa dijawab dengan tepat.

\section{HASIL PENELITIAN DAN PEMBAHASAN}

1. Pondok Pesantren AL-Aqsho Kabupaten Sumedang

a. Pola Budaya Literasi di Pondok Pesantren Al-Aqsho

1) Berbicara

a) Pola budaya literasi aspek berbicara dilakukan dengan cara para santri berbicara dengan menggunakan kosakata berbahasa Arab dan Inggris yang diberikan setiap subuh.

2) Membaca

a) Pola budaya literasi aspek membaca dilakukan dengan cara membiasakan membaca baik bahasa Arab, bahasa Indonesia maupun bahasa Inggris.

3) Menulis

a) Kegiatan yang paling utama dalam bidang menulis adalah mengulang kosakata yang diberikan setiap subuh. Caranya ditulis melalui pembelajaran imla.Di awal diajarkan terlebih dahulu huruf hijaiyah, makharijul huruf, mulai dari huruf tunggal sampai huruf sambung.

b. Respon Guru dan Siswa terhadap Pola Budaya Literasi

1) Di kalangan guru.

Semua guru termasuk guru yang bukan alumni Gontor merespon positif terhadap pengembangan kegiatan literasi yang dilaksanakan di pondok pesantren ini. Sebagai indikator respon positif ini guruguru mengusulkan membuat kelompok atau kelas billingual .

c. Kendala atau Tantangan dalam Pelaksanaan Pola Budaya Literasi

1) Kendala waktu. Waktu yang 24 jam kadang-kadang pembagiannya bentrok dengan kegiatan lain.

2. Pondok Pesantren AL IHSAN Baleendah Kabupaten Bandung

a. Pola Budaya Literasi di Pondok Pesantren Al Ihsan

1) Berbicara

a) Semua santri berada di lokasi Pondok Pesantren selama 24 jam, sehingga secara non formal untuk kegiatan berbicara dengan bahasa asing bisa setiap saat.

2) Membaca 
a) Untuk budaya literasi membaca para santri digiring masuk ke perpusatakaan untuk membaca berbagai buku dan kitab. Kegiatan ini dilakukan pada jam istirahat sekolah atau ketika sore hari ketika jam olahraga, dengan tujuan muncul reading habit di kalangan para santri. Di perpustakaan ini disediakan buku yng beraneka ragam.

3) Menulis

a) Kegiatan menulis dilakukan ketika membuat persiapan pidato, baik mengarang sendiri (bagi yang mampu) bagi yang tidak mampu menyalin atau meringkas dari teks yang sudah ada.

b. Respon Guru dan Siswa terhadap Pola Budaya Literasi

1) Dari Kalangan Guru

Dukungan guru berbeda-beda ada yang mendukung sepenuh hati, ada yang biasa-biasa saja. Guru yang mampu ikut menegur jika menemui pelenggaran pada santri. Guru luar semua mendukung, hanya diantara mereka ada yang mau belajar mengikuti pola tersebut ada yang tidak,terutama guru yang sudah senior atau yang sudah tua.

2) Di Kalangan Siswa

Secara umum para santri sangat mendukung program pengembangan bahasa asing Arab dan Inggris ini. Hal ini dapat dilihat dari antusiasme mereka mengikuti dan melaksanakan semua program pembelajaran baik formal maupun yang non formal.

c. Kendala atau Tantangan dalam Pelaksanaan Budaya Literasi

Kendala yang dialami Pondok ini adalah kurangnya pemeriksa hasil tulisan karya para santri seperti teks pidato .

d. Kepemimpinan

Kepemimpinan kyai dalam mengembangkan budaya literasi unggul di pondok pesantren al aqsha kabupaten Sumedang telah diterima oleh para guru dan santri dengan baik yaitu dengan diimplementasikannyya program-program kyai seperti program pembelajaran dengan bilingual.

Pada Pesantren al-Ihsan kepemimpinan Kyai dalam hal ini pengurus pondok berjalan dengan efektif hal ini terbukti dari tidak adanya guru atau ustad dan santri yang kontra terhadap kebijakan literasi yang dilaksanakan pada pesantren.

Jika dikaitkan dengan teori budaya literasi terkait dengan pola literasi di pesantren, terdapat temuan bahwa pada kedua pesantren, baik pada pesantren al-Aqsho kabupaten Sumedang, maupun pada pesantren al-Ihsan Bale Endah kabupaten Bandung ditemukan pola budaya literasi yang bersifat formal yaitu pola literasi yang dibimbing dan ditentukan dari pimpinan pesantren dengan rangkaian jadwal kegiatan yang menyertainya.

Tetapi yang menarik pada kedua pesantren ini, ternyata ditemukan bahwa keduanya menyelenggarakan kegiatan literasi dengan pola informal yaitu mengadakan berbagai kegiatan yang di desain secara informal dalam bentuk kegiatan kelompok-kelompok diskusi literasi.Hal ini tentunya menarik karena terdapat dua bentuk pola literasi yang secara praktis dijalankan oleh kedua pesantren. Pelaksanaan pola literasi yang efektif dan efisien tentunya akan sangat mendorong bagi penguatan basis literasi pada pesantren. 
Polanya sudah ada tinggal pemberdayaan dari kedua pola yang tersedia, pengembangan pola-pola yang tersedia tersebut perlu mendapat perhatian terutama pada pesantren sebagai basis literasi masyarakat muslim Indonesia. Logikanya, jika masyarakat pesantren sudah terbangun rasa pentingnya terhadap literasi, maka setiap perubahan literasi kearah peningkatan pada pesantren akan membawa arus segar bagi pengembangan literasi di Indonesia.

Sesuai dengan yang diungkapkan Cooper (1993:30) bahwa terdapat tiga komponen yang saling berkaitan dalam program tersebut, yaitu motivasi, pembelajaran baca tulis terpadu, dan kegiatan baca tulis mandiri. Pada studi di pondok pesantren al-Aqsho dan al-Ihsan terdapat keterkaitan antara yang disampaikan Cooper dengan yang terjadi di lapangan. Pesantren dalam hal ini telah memberikan motivasi kepada santri agar memiliki kemampuan dan budaya literasi yaitu dengan cara mengisyaratkan kepada siswa santri untuk membaca buku daras dan pergi ke perpustakaan untuk membaca buku-buku yang ada di perpustakaan.

Dalam analisa ini terdapat kaitan antara budaya literasi dengan motivasi. Logikanya tidak mungkin seorang ustad mengisyaratkan santrinya untuk membaca buku daras dan pergi ke perpustakaan jika tidak ditujukan agar santri memiliki kemampuan membaca dan memahami buku dengan baik. Bahkan motivasi ini cukup besar yaitu dengan mengisyaratkan juga para santri untuk membaca buku di perpustakaan.

Terkait dengan respon guru dan siswa terhadap budaya literasi, respon guru umumnya baik dan mendukung budaya literasi ini. Respon baik ini tentunya akan mendukung budaya literasi di pesantren. Seperti dikatakan Cooper, budaya literasi dapat dilakukan melalui pemotivasian. Respon guru yang baik, dan respon siswa yang baik ini tentunya akan mendorong atau berasal dari adanya motivasi para guru dan siswa untuk membudayakan literasi di pesantren.

Terkait dengan kendala yang dihadapi peantren dalam budaya literasi ini adalah mengenai Sumberdaya Manusia yang masih kurang terutama terkait dengan kurangnya pemeriksa terhadap hasil karya santri. Subandiyah (2015) mengidentifikasi bahwa salah satu kelemahan dan tantangan budaya literasi adalah sumber belajar yang masih kurang. Sumber belajar ini terkait juga dengan SDM. Pada kasus pesatren al-Ihsan permasalahan ini terjadi. Solusinya terkait dengan rekrutmen dan penyediaan SDM yang lebih baik dan banyak lagi meskipun juga terkait dengan aspek lainnya seperti dana.

Terkait dengan kepemimpinan pada kedua pesantren ini, sesuai dengan yang dikatakan oleh Sergiovanni bahwa keunggulan sebuah lembaga ditentukan oleh kepemimpinan terutama dalam membuat cultural force, maka telah dapat dibuktikan bahwa kepemimpinan pada kedua pesantren ini memiliki kemampuan yang baik dalam menciptakan kekuatan dan keunggulan budaya literasi.

\section{KESIMPULAN DAN SARAN}

1. Kesimpulan

a. Pola strategi budaya literasi yang diterapkan di pesantren al- Aqsho kabupaten Sumedang dan Pesantren al- Ihsan Kabupaten Bandung terdiri dari :pola berbicara, pola membaca, pola menulis yang memiliki 
pola yang relative sama karena kedua pesantren ini mendapat pengaruh dari Gontor

b. Respon stakeholder dalam pengembangan budaya literasi pada umumnya sangat mendukung meskipun dengan pola dukungan yang variatif

c. Tantangn yang dihadapi pesantren al- Aqsho dan pesantren al- Ihsan dalam pengembangan budaya literasi adalah kurangnya sumberdaya Manusia (SDM) dan keterlibatan masyarakat yang masih terbatas

2. Saran

d. Kepemimpinan pada kedua pesantren memiliki kemampuan untuk mendorong budaya literasi unggul.

Dari hasil penelitian ini dapat disampaikan beberapa rekomendasi agar budaya literasi berjalan dengan baik pada pesantren, antara lain :

a. Pesantren lebih berperan aktif menjalin kerjasama denngan instansi pemerintah dan masyarakat terutama dalam pengadaan fasilitas seperti buku-buku agar pelaksanaan budaya literasi lebih berjalan dengan lebih baik.

b. Pesantren mengupayakan penambahan sumberdaya manusia terutama terkait dengan hasil-hasil budaya literasi santri

c. Masyarakat dan pemerintah ikut serta membantu budaya literasi di pesantren terutama menyangkut SDM dan fasilitas .

\section{DAFTAR PUSTAKA}

Alwasilah, C. 2007. Pokoknya menulis. Bandung: PT Kiblat Buku Utama.

Cooper, J.D. 1993. Literacy: Helping Children Construct Meaning. Boston Toronto: Hougton Miffin Company.

Dharma, S. 2015. Mengapa Para Ulama tak Bersuara dalam soal kewajiban membaca. Lihat selebihnya di: http://satriadharma.com /2015/10/24/mengapa-para-ulama-tak-bersuara-dalam-soal-kewajibanmembaca/. Diakses pada: 22 Agustus 2016.

Haryanti, T. 2014. Membangun Budaya Literasi Dengan Pendekatan Kultural di Komunitas Adat. http://www.triniharyanti.id /2014/02/ membangunbudaya-literasi-dengan.html

Hayati.2013. Kemampuan Membaca Pemahaman Pada Teks Dalam Bentuk Pilihan Ganda. Tanjungpinang: Universitas Maritim Raja Ali Haji.

Hidayanto, J. 2013. Upaya Meningkatkan Minat Baca Masyarakat melalui Taman Bacaan Masyarakat Area Publik. Semarang: Universitas Negeri Semarang.

Kartika, I. 2008. Kemampuan Pesantren dalam Mengembangkan Pendidikan Keaksaraan. Bandung: FKIP UNINUS

Kern, R. 2000. Literacy and Language Teaching. Oxford: Oxford UniversityPress.

Kurniawati, R. 2010. Kemampuan Membaca Pemahaman Siswa. Surabaya: Universitas Negeri Surabaya

Muttaqin, A. Z. 2015. Membaca dan menulis ujung tombak kemajuan umat Islam. Lihat selebihnya di:https://www.arrahmah.com/kajian-islam/. Diakses pada 16 Agustus 2016. 
Musfiroh dan Lestyarini, B. 2013. Konstruk Kompetensi Literasi Berbasis Konteks Indonesia untuk Siswa Sekolah Dasar.Yogayakarta: Universitas Negeri Yogayakarta.

Nurdin, Diding, 2007. Manajemen Pendidikan dalam IImu dan Aplikasi Pendidikan, Bandung, grasindo

Romdhoni, A. 2012. Al-Qur'an: Memerangi Illiteracy, Mencipta Peradaban IImu Pengetahuan.Journal of Qur'an and Hadith Studies - Vol.1, No.1.

Salman, A. H. 2011. Mungkinkah Membangun Budaya Literasi Pembelajaran Bahasa Arab di Indonesia?. Banjarmasin: Widyaiswara Balai Diklat Keagamaan Banjarmasin

Shihab, M. Q. 1999. Membumikan Al-Qur'an: Fungsi dan Peran Wahyu dalam Kehidupan Masyarakat. Bandung: Mizan.

Spencer, J, E. 1972. Literacy dalam The Encyclopedia Americana International Edition, Vol. 17. New York: Americana Corporation.

Subandiyah, H. 2015. Pembelajaran Literasi dalam Mata PelajaranBahasa Indonesia. Surabaya: Universitas Negeri Surabaya.

Suherli. 2009. Membangun budaya literasi. Lihat selebihnya di: http://suherlicentre.blogspot.com/2009/11/membangun-budayaliterasi.html. Diakses pada tanggal 22 Agustus 2016.

Tebuireng.org.2015. Membangun kembali literasi pesantren. Lihat selengkapnya di:http://tebuireng.org/membangun-kembali-literasipesantren/. Diakses pada 22 Agustus 2016.

Tri, W. 2008. Ketrampilan Literasi dalam Konteks Wacana Bahasa Indonesia, dalam Ranah Menulis Akademik. Jakarta: Fakultas Sastra Universitas Gunadarma.

Rivai dan Murni, Sylviana. 2009. Education Management,Jakarta, Rajawali Press

Wachid, E. P. 2007. Menghidupi Tradisi Literasi: Problematika bagi Siswa, Guru, Sekolah, dan Negara. Lihat selengkapnya di: http://www.titikoma.com/esai, diakses padatanggal 22 Agustus 2016.

Widodo, S. Johan, G. M, dan Ghasya, A. V. 2015. Membangun Kelas Literat Berbasis Pendidikan Lingkungan Hidup untuk Melatihkan Kemampuan Literasi Siswa di Sekolah Dasar. Surabaya: Negeri Surabaya.

Zuhriy S. 2011. Budaya Pesantren dan Pendidikan Karakter pada Pondok

Pesantren Salaf. Yogyakarta: UIN Sunan Kalijaga Yogyakarta 